\title{
Potential of Cryptocurrency as Global Money of the Sixth Technological Mode Based on the Global Financial System
}

\author{
Marat Rashitovich Safiullin ${ }^{1}$, Mikhail Valerievich Savelichev ${ }^{2}$, Leonid Alekseevich Elshin ${ }^{3} \&$ Vadim Olegovich \\ Moiseev $^{4}$ \\ ${ }^{1}$ Economic and Strategic Development, Kazan (Volga Region) Federal University, Science of the State Budgetary \\ Institution Advanced Economic Research Centre at the Academy of Sciences, Kazan Federal University,Republic of \\ Tatarstan \\ ${ }^{2}$ Departments for Qualitative Research, Science of the State Budgetary Institution Advanced Economic Research \\ Centre at the Academy of Sciences, Republic of Tatarstan \\ ${ }^{3}$ Centres for Strategic Assessments and Forecasts, Kazan (Volga Region) Federal University, Kazan, Russia \\ ${ }^{4}$ Department of Business Statistics and Economics, Federal State Budgetary Educational Institution, Higher \\ Education Kazan National Research Technological University, Kazan, Russia \\ Correspondence: Leonid Alekseevich Elshin, Doctor of Economics, Director of the Centre for Strategic Assessments \\ and Forecasts, Kazan (Volga Region) Federal University, Kazan, Russia. Tel: 7-987-297-0679.
}

Received: September 2, 2020

Accepted: November 13, 2020

Online Published: December 15, 2020

doi:10.5430/ijfr.v11n6p296

URL: https://doi.org/10.5430/ijfr.v11n6p296

\begin{abstract}
The change in technological modes is accompanied by financial crises that lead to changes in the global financial system. For a long period, gold played the role of world money. However, the development of technology required the transition to more flexible forms of world money, the basis of which is the national currency of the most industrialized countries. Currently, the transition to the technologies of the Sixth technological mode is accompanied by a global financial crisis. The US dollar does not cope with the functions that the latest technologies present to monetary systems. They are being replaced by a new generation of cryptocurrency-based monetary systems. Cryptocurrencies and blockchain offer new forms of investing, calculating, storing, and saving money. Such financial instruments as various types of cryptocurrencies, tokens, smart contracts, and crypto exchanges offer new opportunities for effective investment in technologies of the Sixth technological mode.
\end{abstract}

Keywords: financial crisis, technological mode, cryptocurrency, blockchain, world money

\section{Introduction}

The development of the capitalist system is associated with the passage of phases of an economic, technological and financial recovery, which are replaced by phases of stagnation, crisis of varying degrees of depth and duration, after which the growth stage begins again. Crises vary in their severity and in coverage of countries in crisis. The development of the capitalist system and its globalization leads to the fact that crises are gaining a global scale. The flip side of high efficiency and productivity for the system of the world division of labor is that crisis phenomena can no longer be localized within the borders of a single country or even a group of countries.

Another integral feature of the world capitalist system is the close interconnection of economic, technological and financial systems. Long waves of development cover all aspects of the world economy, while progress in technology determines the specific characteristics of each period of rising, development and decline of this system. Currently, the Fifth technological stage is gradually being replaced by the Sixth, which is coupled with qualitative changes in the institutional, organizational, and financial structures.

\section{Methods}

According to the evolutionary model of the economic system, its development is determined by the appearance, growth, dominance and attenuation of microgeneration, which are technologically homogeneous aggregates of goods. In turn, microgeneration can be combined according to the similarity of the technologies used into larger macrostructures, or technological modes. (Matveeva \&Semenova, 2013) 
The technological mode is a set of technologically related industries, in the core of which there are the key technologies for that level of development. In total, from the end of the 18th century, five technological modes have changed each other, and at the moment the world system is moving towards the Sixth technological mode.

The spread of new technologies leads to changes in the forms of business organization, to the transition to new methods of investing and financing innovations. The financial system adapts to new production and organization technologies also going through various stages of its development, which can be described as implementation, aggression, synergy, maturity, and crisis. (Perez, 2020) At the implementation stage, financial capital is looking for industries in which it is possible to invest. The next stage is characterized by increased investment activity, since new technologies are in high demand and bring a high rate of return. However, this leads to reinvestment; finances break away from real production; a financial bubble inflates, which leads to a crisis.

The global financial crisis of 2008, which continues to this day, is not unusual for the global economic system. The world economic system goes through such crises quite regularly, and they differ only in-depth and area of distribution. Among the global financial crises are the crisis of 1825-1826, the Great Depression of 1929-1938, the debt crisis in the 1980s, and the global recession of 2008-2020. (Reinhart \& Rogoff, 2009) An important aspect of these crises is the change in the types of the global financial system and, accordingly, the type of world currency.

Thus, the logic of the development of the world capitalist system covers all aspects and forms of its existence. The emergence of new technologies forms a set of related microgeneration, which development is associated with an increase in demand for new products created using new technologies and a corresponding increase in prices. Raising the rate of return on technological innovations attracts in macro-generation the financial capital, which not only expands investment, but also introduces new financial technologies that allow serving new forms and types of goods; in particular, the types of world currencies are changing.

\section{Results and Discussion}

The crisis in Britain in 1825-1826, which became the trigger for the global crisis that covered Europe and Latin America, was associated with the speculations of provincial banks in real and imaginary investments. A financial bubble arose, including due to excessive Latin American debt, which caused the stock market crash, the liquidation of 6 London and 60 provincial banks. Greece, Portugal and almost all Latin American countries defaulted. (Reinhart \& Rogoff, 2009)

This crisis fell on the transition from the First technological mode to the Second related to the emergence of a cluster for the creation and production of steam engines, the development of a cluster of mining and metallurgical industries, the gradual decline in the cluster of cultivation of spinning crops and the flourishing of textile production. (Matveeva \& Semenova, 2013)

At the same time, according to the Paris financial system (1821-1867), the global financial system was based on the gold standard, which meant unhindered gold export and free international gold trade (Andryushin, 2019).

The next global crisis is associated with the Great Depression of 1929-1938, during which thousands of banks and savings and credit organizations went bankrupt in the United States alone. Depression swept almost all regions of the world.

This period was correlated with the completion of the Third and the beginning of the Fourth technological mode. This mode is accounted for the growth of clusters such as ferrous and non-ferrous metallurgy for the production of machine-building alloys and engine building, the military chemical cluster, the nuclear energy cluster, the cluster of gasoline and diesel engines, as well as the telephone and radio, and television communications clusters.

As a result of the Genoese Conference (1922), a gold standard was set, as a result of which the US dollar and the British pound were declared the equivalent of gold and became world money. However, in 1944, following the results of the Bretton Woods Conference, the US dollar became to play the main role in world money, while gold circulation was significantly limited, but the US dollar retained its gold content (Portnoi, 2017).

The period of completion of the Fourth and the transition to the Fifth Technological mode was marked by a debt crisis of the 1980s. The crisis has covered many developing countries in Africa and Latin America, and to a lesser extent in Asia. It was accompanied by state defaults, the collapse of currencies, and high inflation. At this point, the regime of the global financial system was regulated by the Jamaican Agreements (1976-1978), in accordance with which SDRs have been declared as world currency. They are multi-currency baskets, the bulk of which share were US dollars. In fact, it was the US dollar that became the world currency, but this time without any reference to gold.

The global recession in 2008 was also due to the change of technological waves, and the transition of the world system 
from the Fifth to the Sixth technological mode, which is dominated by a new type of technological cluster, i.e. system ones. The specificity of system clusters is that their technologies are not localized within the boundaries of any industries; they permeate the entire production system as a whole. These clusters primarily include the system cluster of ultrafast digital telecommunications, information technology, global information, and intelligent networks (Matveeva et al., 2018).

The current crisis differs from the previous ones in its duration and global nature since the global financial system based on the US dollar has still not been able to offer a new model of the global financial system and the corresponding world currency.

There is still no agreement on what a new model of the global financial system should be, and the very need to leave the Jamaican system is still being called into question. At the same time, an alternative arose that did not exist at previous levels of technological development, namely, the cryptocurrency system. There is still a lot of discussion around it; supporters of centralized monetary systems see it as a threat to the existing global financial system with, in fact, a single emission center for world money: the FRS and the US dollar. (Nakamoto: A Peer-to-Peer Electronic Cash System \& Sinel' nikova-Muryleva et al., 2019).

The financial system integrates financial innovations in the process of technological development that ensure its effectiveness in changing conditions.

Six main types of financial innovations can be distinguished (Perezm, 2002): tools to provide new products and services with capital: tools to support growth and expansion; modernization of financial services as such; profit making and distribution of investments and risks; bond refinancing and asset mobilization; and high-risk innovation. Each of these types of financial innovations can be associated with a particular type of cryptocurrency and blockchain (see Table 1).

Table 1

Type and purpose of financial innovation

A. Providing capital for new products, services, and radical innovations (bank loans, venture capital), attracting large investments and hedging risks, meeting the financial needs of new infrastructure, investing in new types and kinds of goods (program goods)

B. Maintaining growth and expansion to increase innovation or industrial expansion, promoting public funding in exceptional circumstances (financial crisis, social security), promoting production capacities abroad

C. Modernization of financial services as such for the introduction of new technologies, the development of better forms of organization and service for customers

D. Obtaining profit and distribution of investments and risks to attract small investors; new instruments to stimulate high-risk investments

E. Bond refinancing and asset mobilization instruments for deferring debt repayment or restructuring existing bonds, purchasing productive assets, purchasing and mobilizing rent-seeking assets (real estate, futures)
Type of blockchain technologies and types of cryptocurrencies

Blockchain, smart contracts, cryptocurrencies, ICO, tokens

Creation of cryptocurrency based on a fiat monetary system or with gold or other security

\section{Electronic money, cryptocurrency,} blockchain platform, cryptocurrency transactions, cryptocurrency exchange

Crowdfunding based on Blockchain platform, ICO

Cryptocurrency mining, creation of new types of cryptocurrencies for specific tasks, cryptocurrency exchange

F. High-risk innovation through the use of gaps in legislation (fiscal Unsecured Cryptocurrency Transactions shelters, anonymous transactions)

Source: (Perezm, 2002), developed by the authors

Currently, there are two opposing opinions on the possibility and ability of cryptocurrencies to fulfil the role of money, especially global money. (Ciaian et al., 2016 \& Satran, 2013) So, from the point of view of supporters of the cryptocurrency potential, they can substitute fiat money over time, bacause the monetary nature of cryptocurrency is 
determined as follows (Andryushin, 2019):

- Relative rarity and easy divisibility, since it is necessary to use large computing power to mine cryptocurrency, and their emission is limited for most types of cryptocurrencies; due to its digital nature, this asset is easily divided into parts convenient for calculations (Sinel' nikova-Muryleva et al., 2019);

- The elasticity of the cryptocurrency as a monetary asset, which implies its ability to flexibly increase and decrease the supply depending on the demand for money in the economy; the elasticity can be ensured both due to the algorithmically limited number of cryptocurrencies (Nakamoto: A Peer-to-Peer Electronic Cash System) and due to the mechanism of exchange quotes for the cryptocurrency rate at cryptocurrency exchanges;

- Cryptocurrencies provide the convenience of their use, combining the convenience of electronic money and a high degree of protection against counterfeiting, a double-spending, and theft;

- A high degree of security of a cryptocurrency based on blockchain technology makes it convenient to perform the functions of saving (accumulation);

- The intrinsic value of money is also characteristic of cryptocurrencies since significant energy resources are spent for their mining (de Vries, 2018); in addition, there are types of cryptocurrencies with a gold content, which also makes cryptocurrencies suitable for traditional financial calculations;

- Money is considered as such, because society agrees to consider them to be money; that is, the public consensus is needed regarding the adoption of cryptocurrency as a universal measure of value, which seems quite achievable in the conditions of the global financial crisis. Moreover, at the legislative level, cryptocurrencies are more or less accepted as one of the legal means of payment in a number of countries;

- Virtual currencies are legalized in a number of countries included in the G7, as well as in Switzerland, Singapore, and Austria, (Kochergin \& Pokrovskaia, 2020), while taxes are paid for operations with cryptocurrencies. It can be expected that with the increasing involvement of cryptocurrencies in the global financial system, the possibility to pay taxes and fees in cryptocurrencies will be ensured.

According to other opinions (Portnoi, 2017) (Kochergin \& Yangirova, 2019), cryptocurrencies are not full-fledged money, but represent only a new form of the payment system. The main difference of the payment system is that they do not create new money, but transfer existing currencies from one owner to another. The key differences between cryptocurrencies and money are the lack of intrinsic value of the former, the absence of anyone's obligations for goods and services paid for by the cryptocurrency, which requires cryptocurrencies to be linked to fiat money (Cheah \& Fry, 2015).

In our opinion, cryptocurrencies have the potential to become one of the world's or regional currencies over time, given the unique characteristics that this technology possesses (limited emission, crypto protection, decentralized payments, smart contracts, and tokens).(Safiullin et al., 2019) Since the transition to the Sixth Economic Order, technologies has not yet been completed, and the global financial system continues to be in crisis, the search for a new architecture of the global financial system continues.

\section{Summary}

As the historical experience of technological, economic and financial development shows, the transition from one technological mode to another is associated with changes in the global economic and monetary systems. The financial crises that accompanied the change of technological waves were resolved by changing the basic rules of the game and by moving from one type of world monetary system to another.

The debates over what may replace the US dollar are appealing to cryptocurrencies, which are devoid of many shortcomings of fiat currencies, and more importantly, they have expanded potential that ordinary money cannot possess. Therefore, the future fate of cryptocurrencies is determined by public consensus on their status and the conclusion of a new global-scale agreement, which would entrust cryptocurrencies with the functions of world money.

\section{Conclusions}

The swift evolution in technology has given rise to financial crises that resulted in global financial system reforms. The crisis that the global economic and financial system is undergoing is one of the challenging periods that most countries have gone through, with their economies forming the core of the modern production circuit. The depth and intensity of the crisis are defined by several factors, including climatic and even epidemiological. An essential factor in accessing the trend of economic growth is the transformation of the global monetary system. Cryptocurrencies may, in one form or another, determine the basis of a new system. 


\section{Acknowledgements}

The work is performed according to the Russian Government Program of Competitive Growth of Kazan Federal University.

We would like to thank for the preparation of the publication the staff of the State Budgetary Institution Advanced Economic Research Centre at the Academy of Sciences of the Republic of Tatarstan, who are participants in the RFBR scientific project No. 18-010-00536.

This paper was prepared as part of the research project No. 19-18-00202 supported by the Russian Science Foundation.

\section{References}

Andryushin, S. (2019). Monetary systems: from the origins to the crypto currency. Moscow, Sam Poligrafist Publ.

Cheah, E. T., \& Fry, J. (2015). Speculative bubbles in Bitcoin markets? An empirical investigation into the fundamental value of Bitcoin. Economics Letters, 130, 32-36.

Ciaian, P., \& Rajcaniova, M. (2016). The digital agenda of virtual currencies: Can BitCoin become a global currency?. Information Systems and E-Business Management, 14(4), 883-919.

De Vries, A. (2018). Bitcoin's growing energy problem. Joule, 2(5), 801-805.

Kochergi, D. A., \& Yangirova, A. I. (2019). Central bank digital currencies: Key characteristics and directions of influence on monetary and credit and payment systems. Finance: Theory and Practice, 23(4), 80-98. https://doi.org/10.26794/2587-5671-2019-23-4-80-98

Kochergin, D. A., \& Pokrovskaia, N. V. (2020). International Experience of Taxation of Cryptoassets. HSE Economic Journal, 24(1), 53-84.

Matveeva, Y. V., \& Semenova, G. V. (2013). The innovation and modernization waves in socio-economic development: technological modes, macro-economic generation, a view to the future.

Matveeva, Y. V., Semenova, G. V., \& Shironina, V. M. (2018). The innovation and modernization waves in socio-economic development. Technological modes, Macro-Economic Generation, a View to the Future.

Nakamoto, S. (2019). Bitcoin: A peer-to-peer electronic cash system. Manubot.

Perez, C. (2003). Technological revolutions and financial capital. Edward Elgar Publishing.

Portnoi, M. A. (2017). Money in the national and world economy. Moscow, Magister Publ.

Reinhart, C. M., \& Rogoff, K. S. (2009). This time is different: Eight centuries of financial folly. Princeton University Press.

Safiullin, M. R., Savelichev, M. V., \& Elshin, L. A. (2019). Place and evolution of blockchain technology in the system of economic development. Scientific Review: Theory and Practice, 9(8), 1191-1200. https://doi.org/10.35679/2226-0226-2019-9-8-1191-1200

Satran, S. (2013). How did Bitcoin become a real currency?. U.S. News \& World Report. Retrieved from http://money.usnews.com/money/personal-finance/papers/2013/05/15/how-did-bitcoin-become-a-real-currency

Sinel'nikova-Muryleva, E. V., Shilov, K. D., \& Zubarev, A. V. (2019). The essence of cryptocurrencies: descriptive and comparative analysis. Finance: Theory and Practice, 23(6), 36-49. https://doi.org/10.26794/2587-5671-2019-23-6-36-49

\section{Copyrights}

Copyright for this article is retained by the author(s), with first publication rights granted to the journal.

This is an open-access article distributed under the terms and conditions of the Creative Commons Attribution license (http://creativecommons.org/licenses/by/4.0/). 